IZA DP No. 10168

The Impact of Fundamentalist Terrorism on School Enrolment: Evidence from North-Western Pakistan, 2004-09

Sarah Khan

Andrew J. Seltzer

August 2016 


\title{
The Impact of Fundamentalist Terrorism on School Enrolment: Evidence from North-Western Pakistan, 2004-09
}

\author{
Sarah Khan \\ Georg-August-Universität Göttingen \\ Andrew J. Seltzer \\ Royal Holloway, University of London, \\ LSE and IZA \\ Discussion Paper No. 10168 \\ August 2016 \\ IZA \\ P.O. Box 7240 \\ 53072 Bonn \\ Germany \\ Phone: +49-228-3894-0 \\ Fax: +49-228-3894-180 \\ E-mail: iza@iza.org
}

Any opinions expressed here are those of the author(s) and not those of IZA. Research published in this series may include views on policy, but the institute itself takes no institutional policy positions. The IZA research network is committed to the IZA Guiding Principles of Research Integrity.

The Institute for the Study of Labor (IZA) in Bonn is a local and virtual international research center and a place of communication between science, politics and business. IZA is an independent nonprofit organization supported by Deutsche Post Foundation. The center is associated with the University of Bonn and offers a stimulating research environment through its international network, workshops and conferences, data service, project support, research visits and doctoral program. IZA engages in (i) original and internationally competitive research in all fields of labor economics, (ii) development of policy concepts, and (iii) dissemination of research results and concepts to the interested public.

IZA Discussion Papers often represent preliminary work and are circulated to encourage discussion. Citation of such a paper should account for its provisional character. A revised version may be available directly from the author. 


\section{ABSTRACT}

\section{The Impact of Fundamentalist Terrorism on School Enrolment: Evidence from North-Western Pakistan, 2004-09*}

Islamist groups in Afghanistan, Pakistan, and elsewhere have sought to remove females from public life. This paper uses data from Pakistan Social and Living Standards Measurement and the Global Terrorism Database to examine the impact of the Pakistani Taliban's terror campaign in the north-western province of Khyber Pukhtoonkhwa aimed at removing girls from school from the age of 10 . Using a difference-in-difference-indifference approach, we show that low levels of exposure to terrorism had little effect on school enrolment. High levels of exposure reduced the enrolment rate for boys by about 5.5 percent and girls by about 10.5 percent. This decline in enrolment, although strongly significant, is far smaller than has commonly been portrayed in the media. Finally, although the Taliban warned students to enrol in madrassas rather than secular schools, we find no evidence that this led to increased madrassa enrolment in the affected regions.

JEL Classification: O15, I25, D74, O53

Keywords: education, terrorism, Pakistan

Corresponding author:

Andrew Seltzer

Department of Economics

Royal Holloway, University of London

Egham, Surrey TW20 0EX

United Kingdom

E-mail: a.seltzer@rhul.ac.uk

\footnotetext{
* This paper is a revised version of chapter 2 of Sarah Khan's PhD thesis completed at Royal Holloway, University of London. We have benefited from comments and suggestions by Bishnupria Gupta, Juan Pablo Rud, and Diana Weinhold and participants at a seminar at Royal Holloway.
} 


\section{Introduction}

It has been increasingly recognized that conflicts have serious adverse effects on children's educational attainment (UNESCO, 2010) (Justino, 2011). Conflicts can affect schooling through multiple channels. Active conflicts may have direct effects such as the destruction of school buildings or roads needed to reach schools, the loss of teachers to violence or intimidation, the recruitment of children as soldiers, the displacement of students and their families, and the creation of a climate where parents are afraid to let children leave the home. There also exist indirect mechanisms such as reallocation of resources within households; for example, school children needing to find work to replace lost family income. In turn, reduced school attendance may result in a permanent decline in the stock of human capital, both at the individual and more aggregated levels, and to worse health and labour market outcomes. Several studies have shown that these effects can be quite large, depending on the age and enrolment status of children at the time of exposure. Akbulut-Yuksel finds that German children who resided in cities heavily targeted by allied bombings during World War II went on to attain significantly fewer years of schooling and were on average one centimetre shorter than children of same the age in non-targeted areas (Akbulut-Yuksel, 2014). Swee finds that the recruitment of child soldiers during the Bosnian civil war of 1992-95 led to a decrease in the likelihood that students completed secondary education, but had no significant effects on primary education (Swee, 2015). Akresh and de Walque find that school age children exposed to the genocide in Rwanda experienced a drop in completed schooling of almost half a year and were 15 percent less likely to complete 3rd or 4th grade Akresh and de Walque, 2008).

In addition to reducing the overall level of education, conflicts may have important implications for the gender-based education gap. There may exist real or perceived differences by gender in the risk of violence, harassment, or abduction during conflicts; possibly leading to families being less willing to allow girls to attend school. In addition, during a conflict households may reallocate increasingly scarce resources away from daughters and toward sons. Conversely, boys are more likely than girls to be recruited as child soldiers and forced out of school as a result. Previous studies examining genderspecific outcomes have had mixed findings on the relative impact of conflict on boys and girls. Chamarbagwal and Moran examine the effects of the civil war in Guatemala 
and find that during the peak conflict years (1979-84) Mayan girls in areas worst hit by conflict attained 12 percent fewer years of education than in the pre-war period, while for Mayan boys this gap was 15 percent (Chamarbagwala and Morán, 2011). On the other hand, Shemyakina finds that the civil war in Tajikistan had much larger effects on girls than boys (Shemyakina, 2011). Stewart, et. al. study the impact of armed conflict in several African countries and find that in some countries boys' enrolment declines more than girls due to conflict, whereas the reverse is true for other countries (Stewart and Wang, 2001).

An important recent change in the nature of conflict has been the increasing prevalence of Islamic extremist groups with ideological agendas regarding the role of females. These groups follow a strict interpretation of Islamic law that restricts girls from a fairly young age from participating in most activities outside the household, including schooling. In countries including Afghanistan, Nigeria, Pakistan, and Somalia, Islamist movements have engaged in targeted violence at girls and their schools (United Nations, 2016). This sort of targeted violence is likely to amplify the gender-based effects of conflict, and thus conflicts involving these groups are likely to have gender-specific outcomes that are very different from those of other types of conflicts, such as ethnically-motivated civil wars. This paper examines Islamic fundamentalist terrorism and gender gaps in schooling, using the case of the Pakistani province of Khyber Pukhtoonkhwa (henceforth KPK). Beginning in 2007 the Pakistani Taliban engaged in a campaign to remove girls from public life from age 10. Girls under age 10 and all boys were permitted to remain in school, although in some areas they were warned to attend madrassas (religious schools) rather than state schools. The Taliban enforced this edict with violence; bombing schools at night and making threats to both teachers and students. Both boys' and girls' state schools were attacked, although girls schools were disproportionately targeted (Hayat, 2009) (Khan, 2012) (Amin, 2008) (UNESCO, 2010). According to the Global Terrorism Database there were about 80 attacks against schools in 2008 and 2009 (Global Terrorism Database, 2016). Other sources put the numbers much higher (UNESCO, 2010). Individuals speaking out against the edict, such as the teenage blogger and future Nobel laureate Malala Yousafzai, were dealt with harshly ${ }_{1}^{1}$

\footnotetext{
${ }^{1}$ In early 2009, Yousafzai wrote a blog entry exposing how a decree in forbidding girls from attending school was enforced by the Taliban. On 9 October, 2012 Taliban gunmen halted a van transporting Yousafzai and other children home from school, and shot her in the head and neck. When she survived her injuries, a Taliban spokesman promised that they would "finish the job the next time" (Brumfield, 2012 .
} 
Because the Taliban did not have complete military control of Pakistan, this campaign was limited in scope, focussing primarily on KPK in the northwest of the country, close to the Afghanistan border ${ }^{2}$ Even within KPK, there was considerable variation in the pattern of violence. The bulk of the attacks recorded in the Global Terrorism Database occurred in two districts: Peshawar and Swat. Another group of districts experienced at least one attack, but far fewer than either Swat or Peshawar (Bannu, Charsadda, Dir, Hangu, Malakand, Mansehra, Mardan, Nowshera, Swabi, and Tor Ghar). A third group of districts did not experience any attacks (Abbotabad, Batagram, Buner, Chitral, Dera Ismael Khan, Haripur, Karak, Kohat, Kohistan, Lakki Marwat, Shangla, and Tank). The two high exposure districts experienced very different patterns in the timing of attacks. In Swat, the number of attacks was high in 2007 and 2008. However, a successful military operation by the Pakistani Government cleared the Taliban from the area in March 2009. From this point forward, there were no further attacks against schools recorded in the Global Terrorism Database. By contrast, the number of attacks in Peshawar remained high throughout the period of our study.

A variety of media outlets have claimed that the campaign had drastic effects on school enrolment, particularly for girls. For example, IRIN News claimed that terrorist attacks lead to the closure of 900 schools and a nearly 60 per cent fall in girls' enrolment between 2007 and 2009 (Hayat, 2009). An Amnesty International report claimed that thousands of children in KPK had been deprived of an education (UK Home Office, 2012). Other reports claimed that teachers remained too intimidated to return to work long after attacks had taken place, even after the military defeat of the Taliban in Swat (UNESCO, 2010). A 2012 article in the Guardian claimed that even three years after the defeat of the Taliban in Swat, girls' return to schools was an ongoing process Khan, 2012). Although the bulk of media reports claimed that the school bombing campaign had a significant effect on girls' enrolment, some reports claimed that the Taliban's campaign had limited success (Michael and Qasim, 2011). One factor which makes it difficult to assess the veracity of these opposing claims is that the underlying data on school enrolment is not discussed in any report of which we are aware. In many cases the evidence is anecdotal, often based on anonymous interviews with Pakistani Education

\footnotetext{
${ }^{2}$ The Taliban had a strong military presence in KPK and in the Federally Administered Tribal Areas. However, the tribal areas are sparsely populated and Taliban actions in these areas were directed primarily against the Pakistani Military.
} 
Department officials. We are unaware of any systematic attempt to estimate the overall effects across KPK.

Our study relies on a large random sample of households in KPK to examine the determinants of school enrolment and the impact of terrorism in KPK. We use data covering individual children from the Pakistan Social and Living Standards Measurement (henceforth PSLM), a large, nationally-representative household survey conducted annually since 2004. During the period of our study, the PSLM was carried out all four Pakistani provinces (Punjab, Sindh, Balochistan, and KPK) and the Federal Capital Territory in every year. A sixth administrative unit, the Federally Administered Tribal Areas, was not surveyed in all years. The survey is organised at the level of the household and covers education, health, social capital, marriage and fertility, employment, and economic status. We use the PSLM data from 2004-05, the first year the surveys were conducted, to 2008-09, when military operations removed the Taliban from Swat. We link the data from the PSLM to district-level data on terrorist incidents directed against schools from the Global Terrorism Database (GTD). We use this data to create an exposure to terrorism variable, based on year and district. Although the Taliban campaign continued past 2009, we have ended the study at this point because Pakistan experienced a massive flood which covered one fifth of the country in the summer of 2010. KPK, and in particular Peshawar, experienced some of the worst flooding in the country (OCHA, 2010). Many residents from districts that experienced school bombings were forced to relocate because of the flooding, and it is likely that flooding had a much larger effect on school enrolment than did terrorism.

Our empirical strategy is based on a natural experiment created by variation in exposure to terrorism. We estimate the effects of terrorism on schooling, and in particular the differential effect on girls relative to boys, using a difference-in-difference-in-difference approach. The relevant differences are across sex, year - grouped in to the pre-attack years (2004-05, 2005-06, and 2006-07) and the post-attack years (2007-08 and 2008-09) and extent of terrorism across districts. We run separate regressions for primary school age children (age 5 to 9 ), who were in principle not affected by the Taliban edict; secondary school age children (10-14), who were affected by the edict; and upper secondary school age children (15-18), who were also affected by the edict but who differed significantly from the their younger counterparts in terms of observable characteristics. In 
addition, we run separate regressions for religious schools, as the Taliban encouraged both boys and girls to attend madrassas rather than state schools.

Our main result is that the effects of the Taliban's campaign were much more limited than has been suggested by most media accounts. We find no evidence of any decline in enrolment in the low intensity districts. Even in Swat and Peshawar, we find no evidence of a decline in enrolment until 2008-09. The overall decline across all school-age children was on the order of 5.5 percent for boys and 10.5 percent for girls in these districts in 2008-09. As would be expected based on the nature of the Taliban's edict, we find a larger effect for children age 10-18 than those age 5-9. Finally, we find no evidence of students switching from enrolling in state or private schools to enrolling in madrasas. Madrasas accounted for a very small percentage of enrolment in KPK throughout the period.

The outline for the remainder of the paper is as follows. After the introduction, the second section provides a brief history of the conflict in KPK and the Taliban's campaign to remove girls from public life. The third section describes the data used in this paper. The fourth section provides a brief outline of the schooling system in Pakistan and some summary statistics on school enrolment prior to the start of the Taliban's campaign. The fifth section describes our empirical methodology and shows our results. Finally, the sixth section concludes.

\section{The Pakistani Taliban and the conflict in Khyber Pukhtoonkhwa}

Pakistan has experienced a series of civil conflicts dating back to its founding in 1947, following the partition of Colonial India. The country is currently experiencing sectarian conflict in Balochistan, a protracted low-intensity dispute with India over the region of Kashmir, and an Islamist insurgency in the semi-autonomous Federally Administered Tribal Areas (FATA) and in KPK. It is the insurgency by the Tehrik-i-Taliban Pakistan (or Pakistani Taliban) in KPK, which is the focus of our paper. The Taliban were formed in the Tribal Areas, but the vast majority of their attacks against schools have taken place in KPK. This section briefly outlines the history of the Islamist insurgency and the school bombing campaign. 
The origins of the Islamist insurgency date back to the Soviet occupation of Afghanistan in the 1970s. During the occupation of Afghanistan, fighters from Pakistan crossed over the border to fight alongside the Afghani Mujahideen and Taliban (Abbas, 2008). These fighters shared a religious extremist ideology and a predominantly Pashtun ethnicity with their Afghani counterparts. They maintained close ties to the Afghani Taliban and al Qaeda after the end of the Soviet occupation. In addition to drawing membership and support from local tribes, they have also received support from Arab, Chechen, Uzbek, and other foreign fighters who arrived in FATA during the Soviet-Afghan War and following the NATO invasion of Afghanistan. After NATO forces toppled the Afghani Taliban regime in Kabul in the aftermath of the 2001 attacks on the United States, the Taliban regrouped a sizable contingent of forces along sections of the remote and rugged border adjoining their traditional strongholds in Afghanistan (Abbas, 2008). The Taliban found refuge among local tribes in these regions. They were also able to exploit numerous unguarded mountain passes along the 2500 kilometre Pakistan-Afghanistan border that were often only known to locals when they came under attack from Pakistani, Afghani, and American forces (Zaidi, 2010).

After Pakistan entered the War on Terror, its army began hunting the various militant groups with hideouts in the regions along Afghani border. In reaction, between 2002 and 2007 the various Islamist militias in the tribal areas and adjoining regions of KPK united into the Pakistani Taliban (Abbas, 2008). The ultimate goal of the Taliban insurgency is to overthrow the Pakistani government and impose Sharia (strict Islamic) law. Prior to 2007, the activities of the insurgency were concentrated in the rugged, sparsely populated tribal regions, beginning in Waziristan and spreading to Khyber, Orakzai, Kurram, Bajaur, and Mohmand (Abbas, 2008). The attacks during this phase of the insurgency were directed predominantly at Pakistan's security forces. Outside FATA their initial activities were limited to targeted attacks against Pakistani politicians and foreign interests deemed to be supporting the state.

Although the insurgency started in the tribal regions, over time militias also emerged in settled areas of Khyber Pukhtoonkhwa province, particularly districts adjacent to FATA such as Peshawar, Dir, Bannu, and Hangu and in the Swat Valley. Unlike the sparsely-settled tribal belt, where Pakistan's security forces faced the bulk of attacks, in KPK the Taliban's approach was to set up micro-emirates where they enforced an extremist version of religious ideals on the local populations (UNESCO, 2010). Within 
these areas, the Taliban ruthlessly suppressed practices that they consider to be unIslamic. In addition to schools, targets included an international aid and development office in Swabi, historical sites with Buddhist images; video and music shops; and barber shops, due to their practice of shaving beards (BBC News, 2007) (Daily Times, 2007) (Dawn News, 2009) (Pakistan Press Foundation, 2016) (Reuters, 2007). By 2007, the Taliban directly controlled Swat district, one of the two largest urban areas in KPK, and by 2009 they controlled towns within 100 kilometres of Islamabad. In January 2009 the Pakistani government launched Operation Rah-e-Rast II to drive the Taliban out of Swat Valley. The operation ended in July 2009 with Pakistan Army taking control of the district, although reports suggested that many Taliban fighters merged back into the local population (Buneri, 2012). The final school attack in Swat recorded in the GTD database occurred in March 2009. Unlike Swat, attacks against schools continued elsewhere in KPK through the end of our sample period.

One of the Taliban's main tactics in establishing Sharia law was through the control of education. Boys were urged to attend madrassas instead of public schools. Girls over age 9 were banned from school altogether. Demands were issued to close schools. To enforce the ban, the Taliban bombed schools and threatened both teachers and pupils. The targets included both state and private schools, although girls' schools were often singled out. Madrassas were not targeted. The bombings usually took place in the middle of the night. The bombings began in 2007 and were initially concentrated in Swat. In late 2007 and throughout 2008, the attacks on girls' schools spread to adjacent districts, including Dir, Peshawar, Mardan, Charsadda, Bannu, and the tribal regions of FATA and North Waziristan. Most incidents involved physical damage or destruction of school buildings, although a few also had human casualties. A 2010 UNESCO report describes incidents occurring between 2007 and 2009 where teachers were shot, children were injured or killed by bombs detonated at schools, and children were kidnapped from their schools by the Taliban (UNESCO, 2010).

Media reports claimed that the terrorist attacks resulted in considerable disruption to education throughout the region, although the accounts provide conflicting information on the number of schools damaged or destroyed. For example, one report claimed that 900 government and private schools were closed and girls' enrolment fell from 120,000 in 2007 to just 50,000 in 2009 (Hayat, 2009). Another report concluded that 116 girls' schools and 56 boys' schools were destroyed or damaged between 2007 and March 2009 
in Swat alone (Amin, 2008). Another report puts this figure much higher, claiming that the Taliban destroyed over 800 schools throughout KPK and over 400 in Swat alone (Khan, 2012).

\section{Data}

Our data are drawn from two main sources. We use individual-level data from the 200405 to 2008-09 Pakistan Social and Living Standards Measurement survey (PSLM). The PSLM is an annual, nationally representative household survey conducted since 2004-05. The survey was carried out annually in all four Pakistani provinces, but not the tribal region, during the period of our study. The survey covered all areas of the four provinces, except military restricted zones. During the period of our study, there is no mention of any restrictions in KPK. The timing of the surveys is as follows. The fieldwork for the fourth round of the PSLM was conducted in KPK between July 2007 and June 2008, shortly after the first reported school attack in June 2007. The fieldwork for the fifth round was conducted between August 2008 and June 2009, with Swat surveyed between January and June 2009. This coincides roughly with the last attacks in Swat in March of 2009, following the Rah-e-Rast II military operation. The data from the PSLM cover each member of the household and contain information on education, health, social capital, fertility and marriage, employment, and economic status. The sample size is large, averaging about 8,600 households per year in KPK and 51,000 in Pakistan as a whole. Our second main source of data is the Global Terrorism Database (GTD), an open source database containing information on terrorist incidents by place, year, and type of target. The GTD database is the only one of which we are aware that systematically records, dates, locations, and targets and we rely exclusively on this data for the construction of our measure of exposure to terrorism. As our focus in this paper is on school enrolments, we restrict our attention to terrorist incidents against schools.

We have compiled incidents of terrorism against schools by district and year to create our measure of exposure to terrorism. Although the GTD database provides detailed information about the location of incidents, we restrict our analysis to the district level, as this is the level reported in the PSLM. The GTD records 3 incidents in KPK during 2007, 37 in 2008, and 42 in 2009. Most of the attacks in 2008 and early 2009 occurred in Swat. After the Taliban were driven from the Swat Valley, Peshawar became their main 
focus. Our measure of exposure to terrorism is based on the total number of attacks reported in the GTD in each district over the entire sample period 3 Based on the pattern we observe in the data, we have categorized provinces as either NO EXPOSURE (0 attacks), LOW EXPOSURE (experiencing at least one attack, but excluding Swat and Peshawar), or HIGH EXPOSURE (Swat and Peshawar, which together experienced a majority of attacks). ${ }^{4}$ Figure 1 shows a map of KPK and the classification of each district. It can be seen from Figure 1 that most of the districts experiencing attacks were adjacent to the tribal areas, which provided hideouts for the Taliban when they came under threat from Pakistani security forces.

The dependent variable in our regressions is a dummy variable for either enrolment at any type of school or enrolment in a madrassa. This is directly reported in the PSLM. Apart from the exposure to terrorism variables, our regressions include controls for several standard determinants of school enrolment: age and its square; father's and mother's income in log(real rupees), father's and mother's years of education, household size, a dummy for whether the child was the first born, a dummy for whether the child is married, and a dummy for whether the child resides in an urban area. Parental income was not reported in a consistent manner across observations, and there are observations with daily, monthly, and annual values. We have standardised income measures as nominal monthly earnings, which we deflate using World Bank data to obtain real incomes (World Bank, 2016). Table 1 shows variable definitions, summary statistics, and expected effects on the probability of school enrolment for the main independent variables used in our analysis. We reserve discussion of the dependent variable for the next section. The expected signs are drawn from a long literature on schooling in developing countries (Currie and Moretti, 2003) (Glewwe and Jacoby, 1994).

\footnotetext{
${ }^{3}$ As noted in the previous section, the number of attacks recorded in the GTD is lower than in other sources because the GTD only includes attacks where a specific time, location, and target can be identified. We have cross-checked the incidence of terrorism in the GTD with the South Asia Terrorism Portal (another open source data base, which also includes incidents where some of details recorded in the GTD are not known) and there is a strong correlation between the number of incidents recorded (South Asia Terrorism Portal, 2016).

${ }^{4}$ While believe that this variable is a reasonable proxy for exposure to/threat of terrorism experienced by individual children, it is an imperfect measure because 1) it does not account for timing of the attacks relative to the timing of the observation in the PSLM and 2) it is an imperfect measure of the proximity of the attacks to the individual subjects. It is not possible for us to construct more refined measures of exposure as neither the survey date nor the village of residence is included in the PSLM.
} 


\section{IV: Schooling and Enrolment Patterns}

The primary and secondary education system in Pakistan is modelled on the British system and operates as follows (Blood, 1994). Preschool education runs from ages 3-4 and kindergarten at age 5. Formal primary education begins with grade 1 (typically age 6 ) and runs through grade 8 (typically age 14). Primary schooling is divided into junior school (grades 1-5) and middle school (grades 6-8). Secondary (matric level) schooling runs from grades 9 (age 15) through grade 12 (age 18). Unlike in the developed world, primary and secondary education are not compulsory. As a result, some children do not enrol in school at any point and many others interrupt their schooling at some point. Figure 2 shows enrolment rates by age for KPK in 2006-07, the last year prior to school bombings by the Taliban. Figure 2 highlights several aspects of the education system. First, education is far from universal. The highest age-specific enrolment rates occur from about ages 7 to 9 for girls and 6 to 14 for boys, at slightly over 60 and 80 percent of girls and boys, respectively. United Nations figures show that the overall enrolment rate is among the lowest in the world and the gender gap is among the highest Aslam et al. 2008). Secondly, enrolments rates are considerably higher for boys than girls at all ages above 5 . The male/female enrolment ratio is about two to one after age 14 .

In the analysis we assign children into three age groups - ages 5-9, ages 10-14, and ages 15-18 - in order to ensure sufficiently large samples. We chose age boundaries based on the nature of Pakistani school system and the Taliban edict. Some of the boundary age choices are somewhat ad hoc; however, we have done robustness checks on age boundaries and these do not drive any of our main results. The one boundary which is clearly defined is between ages 9 and 10, as this was the age specified by the Taliban edict on girls' schooling. We chose to begin the youngest group at age 5 rather than age 6 following the summary statistics presented in the Annual Reports of the PSLM, which typically groups younger children into ages 5-9 when presenting data on enrolment. In addition, at age 5 children would have generally been attending the same school as their slightly older counterparts. We chose the second split between ages 14 and 15 for two reasons. First, 14 is the standard age at which primary education ends, although it is fairly common for children interrupt their studies at some point and complete primary education at a later age. Secondly, it is evident from figure 2 that age 14 marks the 
beginning of a continuous age-specific decline in boys' enrolment rate $5^{5}$

The nature of the Taliban edict and the underlying schooling system suggest that we would expect the effects of the school bombing campaign to be concentrated in the two older groups. The Taliban edict did not prevent children under age 10 from attending school, so we expect little or no impact for this group either in terms of overall enrolment declines or relative declines for girls. The edict applied to both the middle and oldest group; however, the underlying difference in enrolment rates shown in figure 2 suggest that there were fundamental differences between the groups. It is likely that those who stayed in school past primary education were systematically different from those ending their schooling at a younger age. For example, students continuing on past primary school may have come from wealthier families, who could afford to live in safer areas or attend schools with better security. These families may have been less influenced by the Taliban's threats.

As a first approach to examining the impact of the Taliban's edict on school enrolment, table 2 shows the enrolment rates over our sample period for KPK and Pakistan as a whole split by age group, gender, and year. Table 2 highlights several important features of schooling in KPK. First, boys' enrolment rates in KPK were well above the average for the country for all age groups. However, girls' enrolment rates in KPK were slightly below the national average. The gap between girls' enrolment in KPK and nationwide increases slightly with age. Secondly, at an aggregate level there is not strong evidence of pre-trends in enrolment rates prior to 2007-08. Third, the Taliban's bombing campaign appears to have had little impact at an aggregate level. Enrolment rates across the board increased in 2007-08, and the largest increase was for girls in KPK, the group that was in principle most effected by the school bombings. We revisit this in the next section, introducing controls for individual characteristics and extent of exposure to terrorism.

The evidence from figure 2 and table 3 points to a large gender-based enrolment gap in KPK even prior to the Taliban's bombing campaign. This gap is larger than that of other Pakistani provinces and much larger than that experienced in most developing countries ${ }^{6}$ There are likely multiple reasons behind the historical existence of a gender

\footnotetext{
${ }^{5}$ This decline begins earlier for girls, but continues between ages 14 and 15 .

${ }^{6}$ (Pakistan Bureau of Statistics, 2007) provides gross enrolment rates by province. KPK has the highest enrolment rates for boys and amongst the lowest rates for girls. The male/female ratio for students aged 14-15 attending at the matric level in 2006-07 was 2.5 in KPK, compared to 1.3, 1.4, and 1.8 in Punjab, Sindh, and Balochistan, respectively. (Aslam et al. 2008) state that UNESCO data on school enrolments show that Pakistan has among the largest gender schooling gaps in the world.
} 
gap including geographic isolation due to the mountainous terrain, a lower urbanisation rate than for other provinces, and a deep-rooted conservative Islamic culture.

\section{Empirical Estimation and Results}

The empirical identification strategy used in this paper exploits the variation in intensity of terrorist attacks on schools across time, districts, and gender. We use a differencein-difference-in-difference estimation strategy, whereby the enrolment level in districts which experienced no attacks and the period before the attacks began effectively act as a counter-factual for what enrolment would have been in the absence of terrorist attacks. Exposure to the attacks is identified by residence in a district affected by the attacks during a time period when the attacks were taking place. We identify separate effects for girls and boys, as the Taliban's edict was specifically aimed at girls and girls' schools were disproportionately attacked.

To identify an individual's exposure to violence, we match their district of residence from the PSLM to the intensity of violence identified in the GTD. We then run a series of regressions with the following baseline specification:

$$
\begin{gathered}
E=(F E M A L E) \mu+(Y E A R) \xi+(I N T E N S I T Y) \tau+(I N T E N S I T Y * Y E A R) \gamma+ \\
(I N T E N S I T Y * F E M A L E) \eta+(F E M A L E * Y E A R) \Theta+(I N T E N S I T Y * Y E A R * \\
F E M A L E) \delta+\beta X+\epsilon
\end{gathered}
$$

where the dependant variable is $E$ which measures the enrolment status of the individual, female is a gender dummy, YEAR is a vector of dummy variables for 2007-08 and 200809 (the years affected by attacks, the omitted category is the pre-attack years 2004-05, 2005-06, 2006-7), INTENSITY is a vector of dummies for district category (HIGH = Swat and Peshawar, LOW = Bannu, Charsadda, Dir, Hangu, Malakand, Mansehra, Mardan, Nowshera, Swabi, and Tor Ghar), and $X$ is a matrix of control variables. The control variables include a vector of fairly standard individual-level determinants of school enrolment: age, household size, parental education and income, birth order, and marital status 7

\footnotetext{
${ }^{7}$ See $($ Currie and Moretti, 2003) and (Glewwe and Jacoby, 1994) on the determinants of schooling.
} 
The gender, year, and intensity variables and the gender/year and gender/intensity interactions can be thought of as background controls for underlying differences in these characteristics. The main variables of interest are the interactions between intensity and year and the triple interaction between gender, year, and intensity. The coefficient on the interaction INTENSITY ${ }^{*}$ YEAR is our measure of the impact of conflict for both boys and girls, whereas the coefficient on the triple interaction measures the differential effect between girls and boys. The net effect of terrorism on schooling is $\gamma$ for boys and $\gamma+\delta$ for girls. If the Taliban was able to reduce access to schools one would expect that 1) $\gamma_{H}<0$ and $\gamma_{L}<0$ (a decline in enrolment in the effected districts), 2) $\gamma_{H}<\gamma_{L}$ (a greater decline in the high intensity districts than the low intensity districts), 3) $\delta_{H}<0$ and $\delta_{L}<0$ (a greater decline for girls than for boys in the affected districts), 4) and $\delta_{H}<\delta_{L}$ (a greater relative decline for girls in the high intensity districts).

\section{V.i: Results}

We run the regressions above for the full sample and separately for age groups 5-9, 1014, and 15-18 using probit with robust standard errors. The results are shown in table 3. The first column shows results for the full sample (everyone in the PSLM aged 5-18 living in KPK Khyber province). Columns 2 to 4 divide the sample into age groups 5 to 9,10 to 14 , and 15 to 18 . Table 4 reports the net treatment effect of exposure to terrorism, $\gamma$ for boys and $\gamma+\delta$ for girls, based on the coefficients from table 3 .

It can be seen in table 3 that the coefficients on most of the control variables have the expected signs. Across all age groups, girls are about 26 percent less likely to be enrolled, confirming the gender gap in enrolment illustrated in figure 2. Urban areas have higher enrolment rates for all age cohorts. The coefficients on AGE and $\mathrm{AGE}^{2}$ have positive and negative signs, respectively, implying that the age-enrolment curve follows an inverted U-shape. Household size has a negative effect on the enrolment of those aged 10-18, perhaps because there is a greater need for older children to help with chores in larger households or alternatively because larger households hold more traditional values about education. Being married reduces the likelihood of being enrolled by about 30 percent for the 15-18 age group and has a negative but not significant effect on the 10-14 age group 8 Being employed reduces the likelihood of attending school by about 40 to

\footnotetext{
${ }^{8}$ We have also run the regressions including the interaction of FEMALE and MARRIED, to determine whether marital status has a different effect for boys and girls. The regressions coefficients do not change substantially from those reported, because few boys in the sample were married.
} 
50 percent. Parents' education has a positive effect on the likelihood of enrolment. The estimates imply that a one year increase in the education level of either parent increases the likelihood that the child is enrolled by about 2-3 percent. The one seemingly counterintuitive result in table 3 is for parental income, with father's income having a negative effect on enrolment probability and mother's income having no significant effect. The standard interpretation of the coefficients on parental income is that it reflects a pure income effect and that children's education is a normal good. An alternative explanation consistent with the observed negative coefficient, is that parents' income is correlated with unmeasured local labour market opportunities. In areas where opportunities are absent, the earnings of parents and any working children will both be low. Low potential earnings implies that the opportunity cost for children to enrol in school is also likely to be low.

The most important results in tables 3 and 4 pertain to the interaction of year and district and the triple interaction of year, district, and sex. Enrolment in the low-intensity districts does not appear to have been greatly affected by the bombings. Although the coefficient on $\mathrm{L}_{-} \mathrm{INT}^{*} 2008$-09 is negative in the full sample regression, an examination of the regressions split by age show that it is only significant for those age 5-9, the group that was in principle unaffected by the Taliban's edict. An examination of the net effects across the different age groups and years in table 4 shows no evidence of substantial declines in enrolment possibilities. In most cases the estimated change in probability is very close to zero, and the only "large" estimated change (for girls age 10-14) is positive. On the other hand there is strong evidence of a decline in the likelihood of enrolment in Swat and Peshawar in 2008-09. Consistent with the nature of the Taliban edict, this probability is larger for girls than for boys and is larger for pupils aged 10-18 than those aged 5-9. The figures in table 4 imply declines in enrolment probability of approximately 5.5 percent and 10.5 percent for boys and girls aged 5-18, respectively. Splitting the results by age group, table 4 implies that there was no decline for boys aged 5-9 and approximately an 8.0 percent decline for boys aged 10-18. These figures for girls were approximately 6.5 percent and 13 percent, respectively. This result is also consistent with an existing literature on schooling and conflict which finds that there are much larger effects on secondary school enrolment than on primary school enrolment (Justino, 2011). Although our estimates suggest that the Taliban's campaign did have an adverse impact on education, particularly for girls over age 10, they do not support 
the much stronger claims made in the media, suggesting enrolment declines of over 50 percent (Hayat, 2009).

\section{V.ii: Madrassa enrolment}

The Taliban's campaign was directed at state and private schools. Madrassas, which teach a religious curriculum, rather than the Ministry of Education-approved curriculum, were not the targets of threats or violence. Some of the threatening letters sent by the Taliban urged pupils to join madrassas in place of secular schools. One possible consequence of the Taliban's campaign is that parent withdrew their children from state and private schools and enrolled them in Madrassas. This would not show up in the regressions in table 3 (which treat all enrolments as equivalent), but would nevertheless have important implications for students' education.

Madrassa education had been increasing nationwide since the 1990s as a result of General Zia ul-Haq's Islamisation program (Focus, 2014). A 2014 report claimed that nationwide there were about 22,000 madrassas which educated about 200,000 full time students and many more part time students. However, KPK never had a high proportion of students enrolled in madrassas. Data from the PSLM surveys show that less than two percent of students in KPK enrolled in madrassas over the period of our study. Other scholars have emphasised that madrassas were only prevalent in low-income areas without public or private schooling options. There had been a dramatic long-term increase in the number of private primary and secondary schools prior to the period of our study. In 1983 there were approximately 3,300 private primary and secondary schools in the four provinces (Jimenez and Tan, 1987). This increased to approximately 32,000 private schools by 2000, a nearly ten-fold increase (Andrabi et al. 2006). This suggests that, absent any increases in enrolments due to Taliban threats, there were limits to the growth of madrassa enrolments.

There is mixed evidence in the popular media as to whether the Taliban's campaign had a dramatic effect on madrassa enrolment. A New York Times report on madrassas and militancy does not mention KPK and notes that most of the country's registered madrassas were in Punjab (Tavernise, 2009). On the other hand, a PBS Frontline report argued that madrassas were becoming increasingly popular with poor families (PBS Frontline, 2010). A Focus report after the period of our study argued that madrassa 
enrolment in 2014 was higher than it had ever been, largely because of the effects of the Taliban's campaign (Focus, 2014).

To examine the importance switching from state or private schools to madrassas we rerun the regressions in table 3 , changing the dependent variable to a dummy for enrolment in a madrassa. The PSLM reports school type, and we have constructed a dummy variable equalling one if enrolled in a madrassa and zero if enrolled in another type of school. We regress this on the same set of independent variables as in table 3 . We have run specifications that are analogous to those in table 3 and specifications with the sample split by gender. The results of the regressions are shown in table 5 .

The coefficients on the control variables in table 5 are broadly similar to those in table 3. An interesting finding is that the coefficients on high and low intensity districts are significantly negative. Baseline madrassa enrolment throughout KPK was low, but it was particularly low in the districts that later suffered attacks 9 The coefficients on the interactions between intensity and year and the triple interactions between intensity, year, and gender identify the effects of the bombings on madrassa enrolment. These coefficients provide no evidence to suggest that madrassa enrolment increased due to the Taliban attacks. Most of the relevant coefficients are insignificant, and those that are significant have a negative sign. The response of parents, if any, was to withdraw students from regular schools, not switch them into madrassas. These findings are broadly in line with those of Khwaja, who argues that in settlements where regular schooling options exist, madrassa enrolment was low and had shown no evidence of significant increases in the year leading up to the Taliban campaign Andrabi et al. 2006).

\section{Conclusion}

This paper examines the impact of the Pakistani Taliban's campaign beginning in 2007 to force girls in Khyber Pukhtoonkhwa Province to stop attending school from age 10. This campaign was enforced with a combination of attacks on schools and threats to both pupils and teachers. Direct violence against those attending school did not occur

\footnotetext{
${ }^{9}$ One interpretation of this finding is that the Taliban were directly targeting areas where secular education was preferred to religious education. While we do not explore the motivation behind the specific pattern of attacks in this paper, we believe that this would be a fruitful area for future research.
} 
during the period of our study. We examine enrolment rates using data from Pakistan Social and Living Standards Measurement and the Global Terrorism Database and a difference-in-difference-in-difference approach to estimate the effects of terrorism on the age-specific enrolment rates of both boys and girls. We identify exposure to terrorism by the interaction of district and year, reflecting the facts that 1) there was considerable variation in the number of attacks across districts, with most of the attacks occurring in either Swat or Peshawar and several districts not experiencing any attacks and 2) there were no attacks prior to 2007 .

Our results suggest that there was a relatively modest decline in enrolment of about 5.5 percent for boys and 10.5 percent for girls in the Swat or Peshawar districts in 2008-09. We find no evidence of any effect in other districts experiencing at least one attack. We also find no evidence that students in KPK were more likely to enrol in madrassas as a result of exposure to the attacks. While the effect on overall enrolment is far from trivial, it is much more modest than has often been portrayed in the popular media, which has claimed that there were hundreds of schools closed in the affected regions and declines in enrolment of over 50 percent. 


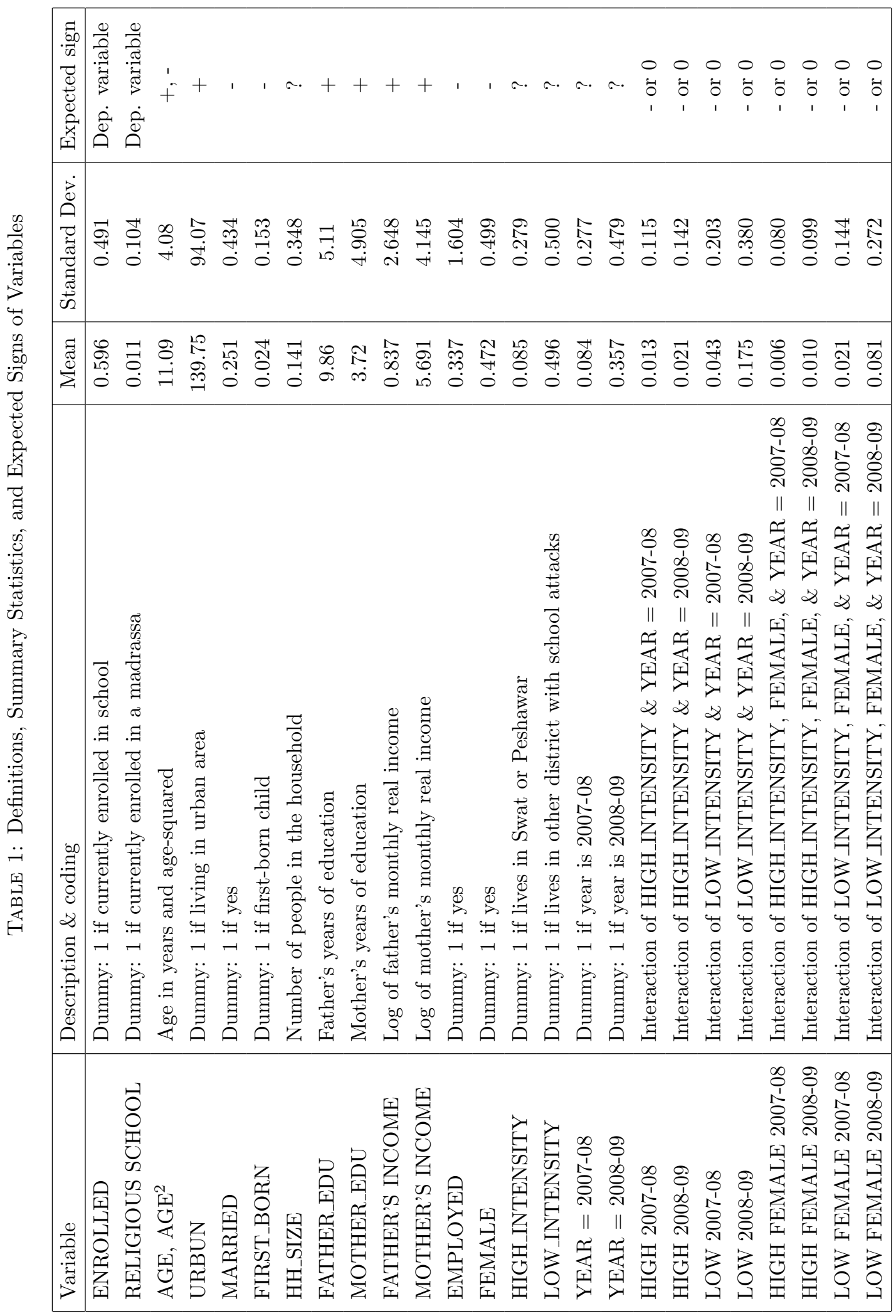


TABLE 2: Enrolment rates by age group: Pakistan and KPK, $2004-2009$

\begin{tabular}{|c|ccc|ccc|}
\hline & \multicolumn{3}{|c|}{ PAK } & \multicolumn{3}{c|}{ KPK } \\
& Ages 5-9 & Ages 10-14 & Ages 15-18 & Ages 5-9 & Ages 10-14 & Ages 15-18 \\
\hline 2004-05 & 64.9 & 73.3 & 45.3 & 70.0 & 81.9 & 53.0 \\
$2005-06$ & 64.2 & 73.5 & 45.9 & 67.1 & 81.3 & 52.7 \\
$2006-07$ & 66.3 & 74.0 & 44.9 & 67.5 & 80.7 & 55.1 \\
$2007-08$ & 69.0 & 76.7 & 46.6 & 72.5 & 83.1 & 58.5 \\
$2008-09$ & 71.0 & 78.2 & 48.4 & 73.6 & 87.1 & 60.2 \\
\hline
\end{tabular}

A. Boys

\begin{tabular}{|c|ccc|ccc|}
\hline & \multicolumn{3}{|c|}{ PAK } & \multicolumn{3}{c|}{ KPK } \\
& Ages 5-9 & Ages 10-14 & Ages 15-18 & Ages 5-9 & Ages 10-14 & Ages 15-18 \\
\hline 2004-05 & 52.9 & 53.6 & 29.5 & 51.9 & 47.7 & 24.5 \\
2005-06 & 53.8 & 55.4 & 29.1 & 52.0 & 51.1 & 26.6 \\
2006-07 & 54.8 & 54.1 & 31.0 & 51.2 & 48.6 & 25.4 \\
2007-08 & 59.4 & 57.4 & 32.2 & 58.9 & 55.3 & 32.2 \\
2008-09 & 59.2 & 57.5 & 33.0 & 57.1 & 54.0 & 30.2 \\
\hline
\end{tabular}

B. Girls 
TABLE 3: Probit regressions on enrolment status in KPK, $2004-2009$

\begin{tabular}{|c|c|c|c|c|}
\hline Currently Enrolled & Full Sample & Age 5-9 & Age 10-14 & Age 15-18 \\
\hline Age & $\begin{array}{c}0.213^{* * *} \\
(0.003)\end{array}$ & $\begin{array}{c}0.609^{* * *} \\
(0.003)\end{array}$ & $\begin{array}{c}0.074^{* *} \\
(0.004)\end{array}$ & $\begin{array}{c}0.476^{* * *} \\
(0.114)\end{array}$ \\
\hline $\mathrm{Age}^{2}$ & $\begin{array}{c}-0.010^{* * *} \\
(0.001)\end{array}$ & $\begin{array}{c}-0.036^{* * *} \\
(0.002)\end{array}$ & $\begin{array}{c}-0.005^{* * *} \\
(0.001)\end{array}$ & $\begin{array}{c}-0.017^{* * *} \\
(0.003)\end{array}$ \\
\hline Hh size & $\begin{array}{c}-0.005^{* * *} \\
(0.001)\end{array}$ & $\begin{array}{c}-0.005^{* * *} \\
(0.001)\end{array}$ & $\begin{array}{c}-0.007 * * * \\
(0.001)\end{array}$ & $\begin{array}{c}-0.001^{*} \\
(0.001)\end{array}$ \\
\hline Married & $\begin{array}{c}-0.312^{* * *} \\
(0.002)\end{array}$ & & $\begin{array}{l}-0.093 \\
(0.006)\end{array}$ & $\begin{array}{c}-0.297^{* * *} \\
(0.01)\end{array}$ \\
\hline First Born & $\begin{array}{c}-0.002 \\
(0.008)\end{array}$ & $\begin{array}{l}-0.009 \\
(0.01)\end{array}$ & $\begin{array}{c}-0.001 \\
(0.008)\end{array}$ & $\begin{array}{c}0.006 \\
(0.008)\end{array}$ \\
\hline Urban & $\begin{array}{c}0.085^{* * *} \\
(0.004)\end{array}$ & $\begin{array}{c}0.078^{* * *} \\
(0.006)\end{array}$ & $\begin{array}{c}0.091^{* * *} \\
(0.006)\end{array}$ & $\begin{array}{c}0.077^{* * *} \\
(0.008)\end{array}$ \\
\hline Father Edu & $\begin{array}{c}0.024^{* * *} \\
(0.001)\end{array}$ & $\begin{array}{c}0.020^{* * *} \\
(0.001)\end{array}$ & $\begin{array}{c}0.024^{* * *} \\
(0.001)\end{array}$ & $\begin{array}{c}0.028^{* * *} * \\
(0.001)\end{array}$ \\
\hline Mother Edu & $\begin{array}{c}0.025^{* * *} \\
(0.001)\end{array}$ & $\begin{array}{c}0.022^{* * *} \\
(0.001)\end{array}$ & $\begin{array}{c}0.022^{* * *} \\
(0.003)\end{array}$ & $\begin{array}{l}.032^{* * *} \\
(0.002)\end{array}$ \\
\hline Father's Income & $\begin{array}{c}-0.010^{* * *} \\
(0.001)\end{array}$ & $\begin{array}{c}0.011^{* * *} \\
(0.001)\end{array}$ & $\begin{array}{c}-0.010^{* * *} \\
(0.001)\end{array}$ & $\begin{array}{c}-0.010^{* * *} \\
(0.001)\end{array}$ \\
\hline Mother's Income & $\begin{array}{l}0.0005 \\
(0.001)\end{array}$ & $\begin{array}{l}-.0001 \\
(0.002)\end{array}$ & $\begin{array}{l}-0.001 \\
(0.002)\end{array}$ & $\begin{array}{c}0.003 \\
(0.002)\end{array}$ \\
\hline Year $=2007-08$ & $\begin{array}{l}0.005 \\
(0.01)\end{array}$ & $\begin{array}{l}0.030 \\
(0.02)\end{array}$ & $\begin{array}{l}-0.033 \\
(0.02)\end{array}$ & $\begin{array}{l}0.016 \\
(0.03)\end{array}$ \\
\hline Year $=2008-09$ & $\begin{array}{c}0.098^{* * *} * \\
(0.01)\end{array}$ & $\begin{array}{c}0.010^{* * *} \\
(0.01)\end{array}$ & $\begin{array}{c}0.120^{* * *} \\
(0.01)\end{array}$ & $\begin{array}{c}0.076^{* * *} \\
(0.01)\end{array}$ \\
\hline Female & $\begin{array}{c}-0.260^{* * *} \\
(0.01)\end{array}$ & $\begin{array}{c}-0.156^{* * *} \\
(0.01)\end{array}$ & $\begin{array}{c}-0.320^{* * *} \\
(0.01)\end{array}$ & $\begin{array}{c}-0.295^{* * *} \\
(0.01)\end{array}$ \\
\hline High Intensity & $\begin{array}{l}0.003 \\
(0.01)\end{array}$ & $\begin{array}{l}0.004 \\
(0.02)\end{array}$ & $\begin{array}{l}0.005 \\
(0.02)\end{array}$ & $\begin{array}{c}-0.004 \\
(0.02)\end{array}$ \\
\hline Low Intensity & $\begin{array}{c}0.025^{* * *} \\
(0.01)\end{array}$ & $\begin{array}{c}0.053^{* * *} \\
(0.01)\end{array}$ & $\begin{array}{l}0.011 \\
(0.01)\end{array}$ & $\begin{array}{l}-0.010 \\
(0.01)\end{array}$ \\
\hline $\operatorname{High}^{*} 2007-08$ & $\begin{array}{c}0.096^{* * *} \\
(0.02)\end{array}$ & $\begin{array}{c}0.105^{* * *} \\
(0.03)\end{array}$ & $\begin{array}{c}0.074^{* *} \\
(0.04)\end{array}$ & $\begin{array}{c}0.087^{*} \\
(0.05)\end{array}$ \\
\hline Low $* 2007-08$ & $\begin{array}{l}0.023 \\
(0.02)\end{array}$ & $\begin{array}{l}-0.011 \\
(0.03)\end{array}$ & $\begin{array}{c}0.080^{* * *} \\
(0.02)\end{array}$ & $\begin{array}{l}0.005 \\
(0.03)\end{array}$ \\
\hline $\operatorname{High}^{*} 2008-09$ & $\begin{array}{c}-0.056^{* * *} \\
(0.02)\end{array}$ & $\begin{array}{l}-0.008 \\
(0.03)\end{array}$ & $\begin{array}{c}-0.081^{* *} \\
(0.04)\end{array}$ & $\begin{array}{c}-0.083^{* *} \\
(0.04)\end{array}$ \\
\hline Low*2008-09 & $\begin{array}{c}-0.025^{* *} \\
(0.01)\end{array}$ & $\begin{array}{c}-0.045^{* * *} \\
(0.02)\end{array}$ & $\begin{array}{l}-0.016 \\
(0.02)\end{array}$ & $\begin{array}{l}-0.001 \\
(0.02)\end{array}$ \\
\hline High*Female & $\begin{array}{c}-0.029^{*} \\
(0.02)\end{array}$ & $\begin{array}{r}-0.020 \\
(0.03)\end{array}$ & $\begin{array}{c}-0.015 \\
(0.03)\end{array}$ & $\begin{array}{c}-0.075^{* *} \\
(0.03)\end{array}$ \\
\hline Low*Female & $\begin{array}{l}-0.004 \\
(0.01)\end{array}$ & $\begin{array}{l}-0.022 \\
(0.01)\end{array}$ & $\begin{array}{l}0.002 \\
(0.01)\end{array}$ & $\begin{array}{l}0.018 \\
(0.02)\end{array}$ \\
\hline Female*2007-08 & $\begin{array}{l}0.032^{*} \\
(0.02)\end{array}$ & $\begin{array}{l}0.006 \\
(0.03)\end{array}$ & $\begin{array}{c}0.059^{* *} \\
(0.02)\end{array}$ & $\begin{array}{l}0.026 \\
(0.04)\end{array}$ \\
\hline Female*2008-09 & $\begin{array}{c}-0.049^{* * *} \\
(0.01)\end{array}$ & $\begin{array}{c}-0.045^{* * *} \\
0.017\end{array}$ & $\begin{array}{c}-0.073^{* * *} \\
0.018\end{array}$ & $\begin{array}{c}-0.037^{*} \\
0.022\end{array}$ \\
\hline High $^{*}$ Female*2007-08 & $\begin{array}{c}-0.080^{* *} \\
(0.04)\end{array}$ & $\begin{array}{c}-0.064 \\
(0.05)\end{array}$ & $\begin{array}{c}-0.079 \\
(0.06)\end{array}$ & $\begin{array}{l}-0.091 \\
(0.07)\end{array}$ \\
\hline Low*Female*2007-08 & $\begin{array}{l}0.004 \\
(0.03)\end{array}$ & $\begin{array}{c}0.049 \\
(0.4)\end{array}$ & $\begin{array}{l}-0.062 \\
(0.04)\end{array}$ & $\begin{array}{l}0.009 \\
(0.05)\end{array}$ \\
\hline High*Female*2008-09 & $\begin{array}{l}-0.048 \\
(0.03)\end{array}$ & $\begin{array}{l}-0.057 \\
(0.05)\end{array}$ & $\begin{array}{l}-0.047 \\
(0.05)\end{array}$ & $\begin{array}{c}-0.062 \\
0.064\end{array}$ \\
\hline Low*Female*2008-09 & $\begin{array}{c}0.037^{* *} \\
(0.02)\end{array}$ & $\begin{array}{c}0.060^{* * *} \\
(0.02)\end{array}$ & $\begin{array}{l}0.030 \\
(0.02)\end{array}$ & $\begin{array}{l}0.007 \\
(0.03)\end{array}$ \\
\hline Observations & 96,773 & 38,875 & 33,282 & 24,614 \\
\hline
\end{tabular}

Notes: Standard errors in parentheses. * indicates significance at a 10 percent level. ** indicates significance at a 5 percent level. * indicates significance at a 1 percent level. 
TABLE 4: Marginal impact of terrorism on the probability of enrolment, KPK

\begin{tabular}{|l|c|c|cccc|}
\hline Gender & Years & Intensity & Age 5-9 & Age 10-14 & Age 15-18 & Age 5-18 \\
\hline Male & $2007-08$ & & 0.105 & 0.074 & 0.087 & 0.096 \\
Female & $2007-08$ & High & 0.041 & -0.005 & -0.004 & 0.016 \\
Male & $2008-09$ & & -0.008 & -0.081 & -0.083 & -0.056 \\
Female & $2008-09$ & & -0.065 & -0.138 & -0.130 & -0.104 \\
\hline Male & $2007-08$ & & -0.011 & 0.077 & 0.005 & 0.023 \\
Female & $2007-08$ & Low & 0.038 & 0.015 & 0.013 & 0.027 \\
Male & $2008-09$ & & -0.045 & -0.016 & -0.001 & -0.025 \\
Female & $2008-09$ & & 0.015 & 0.044 & 0.029 & -0.018 \\
\hline
\end{tabular}

Source: Table 3

Notes: The change in enrolment is measured relative to no attacks districts and to the survey years 2004-05, 2005-06, and 2006-07. For boys this is given by the coefficients on the intensity/year interactions (e.g. HIGH*2007-08, LOW*2007-08, etc.). For girls it is given by the sum of the coefficients on the intensity/year interactions and the intensity/gender/year interaction (e.g. HIGH*2007-08 + HIGH*FEMALE*2007-08). 
TABLE 5: Probit regressions on madrassa enrolment in KPK, $2004-2009$

\begin{tabular}{|c|c|c|c|c|c|c|}
\hline Currently Enrolled & Full sample & Boys & Girls & Age 5 to 9 & Age 10 to 14 & Age 15 to 18 \\
\hline Age & $\begin{array}{c}0.0024^{* * * *} \\
(0.00) 1\end{array}$ & $\begin{array}{c}0.003^{* *} \\
(0.001)\end{array}$ & $\begin{array}{c}0.002 \\
(0.001)\end{array}$ & $\begin{array}{c}0.007 \\
(0.006)\end{array}$ & $\begin{array}{l}0.020^{*} \\
(0.011)\end{array}$ & $\begin{array}{l}-0.016 \\
(0.04)\end{array}$ \\
\hline $\mathrm{Age}^{2}$ & $\begin{array}{c}-0.00005 \\
(0.001)\end{array}$ & $\begin{array}{c}-0.00007 \\
(0.001)\end{array}$ & $\begin{array}{c}-0.00002 \\
(0.001)\end{array}$ & $\begin{array}{c}-0.0004 \\
(0.001)\end{array}$ & $\begin{array}{c}-0.0008^{*} \\
(0.001)\end{array}$ & $\begin{array}{l}0.0006 \\
(0.001)\end{array}$ \\
\hline Hh size & $\begin{array}{c}-0.0004^{* * *} \\
(0.001)\end{array}$ & $\begin{array}{c}-0.0004^{* * *} \\
(0.001)\end{array}$ & $\begin{array}{r}-0.0002 \\
(0.001)\end{array}$ & $\begin{array}{c}-0.0004^{* * *} \\
(0.001)\end{array}$ & $\begin{array}{c}-0.0004^{*} \\
(0.001)\end{array}$ & $\begin{array}{l}-0.0002 \\
(0.001)\end{array}$ \\
\hline Married & $\begin{array}{l}0.005 \\
(0.01)\end{array}$ & $\begin{array}{l}0.026 \\
(0.02)\end{array}$ & & & $\begin{array}{l}0.053 \\
(0.05)\end{array}$ & $\begin{array}{l}-0.002 \\
(0.01)\end{array}$ \\
\hline First Born & $\begin{array}{l}0.003^{* *} \\
(0.001)\end{array}$ & $\begin{array}{l}0.003^{*} \\
(0.002)\end{array}$ & $\begin{array}{c}0.003 \\
(0.003)\end{array}$ & $\begin{array}{c}-0.0005 \\
(0.002)\end{array}$ & $\begin{array}{c}0.008^{* * *} \\
(0.003)\end{array}$ & $\begin{array}{c}-1.41 \mathrm{E}-05 \\
(0.003)\end{array}$ \\
\hline Urban & $\begin{array}{c}-0.007^{* * *} \\
(0.001)\end{array}$ & $\begin{array}{c}-0.006^{* * *} \\
(0.001)\end{array}$ & $\begin{array}{c}-0.008^{* * *} \\
(0.002)\end{array}$ & $\begin{array}{c}-0.004^{* * *} \\
(0.001)\end{array}$ & $\begin{array}{c}-0.008^{* * *} \\
(0.002)\end{array}$ & $\begin{array}{c}-0.010^{* * *} \\
(0.003)\end{array}$ \\
\hline Father Edu & $\begin{array}{c}-0.00003 \\
(0.001)\end{array}$ & $\begin{array}{c}-0.0002^{*} \\
(0.001)\end{array}$ & $\begin{array}{l}0.0002 \\
(0.001)\end{array}$ & $\begin{array}{l}0.0002 \\
(0.001)\end{array}$ & $\begin{array}{l}-0.0001 \\
(0.001)\end{array}$ & $\begin{array}{c}-0.0003 \\
(0.001)\end{array}$ \\
\hline Mother Edu & $\begin{array}{c}-0.0007^{* * *} \\
(0.001)\end{array}$ & $\begin{array}{c}-0.0006^{*} \\
(0.001)\end{array}$ & $\begin{array}{c}-0.0008^{* *} \\
(0.001)\end{array}$ & $\begin{array}{c}-0.0005 \\
(0.001)\end{array}$ & $\begin{array}{c}-0.0004 \\
(0.001)\end{array}$ & $\begin{array}{c}-0.002^{* * *} \\
(0.001)\end{array}$ \\
\hline Father's Income & $\begin{array}{l}0.0002^{*} \\
(0.001)\end{array}$ & $\begin{array}{l}0.0002 \\
(0.001)\end{array}$ & $\begin{array}{l}0.0002 \\
(0.001)\end{array}$ & $\begin{array}{l}0.0001 \\
(0.001)\end{array}$ & $\begin{array}{l}0.0003 \\
(0.001)\end{array}$ & $\begin{array}{l}0.0001 \\
(0.001)\end{array}$ \\
\hline Mother's Income & $\begin{array}{l}.00009 \\
(0.001)\end{array}$ & $\begin{array}{l}.00002 \\
(0.001)\end{array}$ & $\begin{array}{l}0.0002 \\
(0.001)\end{array}$ & $\begin{array}{r}-0.0002 \\
(0.001)\end{array}$ & $\begin{array}{l}0.0001 \\
(0.001)\end{array}$ & $\begin{array}{l}0.0006 \\
(0.001)\end{array}$ \\
\hline Year $=2007-08$ & $\begin{array}{c}0.004 \\
(0.003)\end{array}$ & $\begin{array}{c}0.004 \\
(0.003)\end{array}$ & $\begin{array}{c}-0.008^{* * *} \\
(0.003)\end{array}$ & $\begin{array}{l}-0.003 \\
(0.003)\end{array}$ & $\begin{array}{l}0.013^{*} \\
(0.007)\end{array}$ & $\begin{array}{c}0.005 \\
(0.009)\end{array}$ \\
\hline Year $=2008-09$ & $\begin{array}{l}-0.002 \\
(0.002)\end{array}$ & $\begin{array}{l}-0.001 \\
(0.002)\end{array}$ & $\begin{array}{c}-0.009 * * * \\
(0.002)\end{array}$ & $\begin{array}{c}-0.006^{* * *} \\
(0.002)\end{array}$ & $\begin{array}{c}0.001 \\
(0.003)\end{array}$ & $\begin{array}{l}.00003 \\
(0.004)\end{array}$ \\
\hline Female & $\begin{array}{c}0.006^{* * *} \\
(0.002)\end{array}$ & & & $\begin{array}{c}0.006^{* *} \\
(0.002)\end{array}$ & $\begin{array}{c}0.005 \\
(0.003)\end{array}$ & $\begin{array}{c}0.006 \\
(0.006)\end{array}$ \\
\hline High Intensity & $\begin{array}{c}-0.011^{* * * *} \\
(0.002)\end{array}$ & $\begin{array}{c}-0.010^{* * *} \\
(0.002)\end{array}$ & $\begin{array}{c}-0.014^{* * *} \\
(0.002)\end{array}$ & $\begin{array}{c}-0.006^{* * *} \\
(0.002)\end{array}$ & $\begin{array}{c}-0.012^{* * *} \\
(0.003)\end{array}$ & $\begin{array}{c}-0.019^{* * *} \\
(0.003)\end{array}$ \\
\hline Low Intensity & $\begin{array}{c}-0.009^{* * *} \\
(0.002)\end{array}$ & $\begin{array}{c}-0.009^{* * *} \\
(0.002)\end{array}$ & $\begin{array}{c}-0.009^{* * *} \\
(0.002)\end{array}$ & $\begin{array}{c}-0.005^{* *} \\
(0.002)\end{array}$ & $\begin{array}{c}-0.011 * * * \\
(0.003)\end{array}$ & $\begin{array}{c}-0.016^{* * *} \\
(0.005)\end{array}$ \\
\hline High*2007-08 & $\begin{array}{l}-0.005 \\
(0.01)\end{array}$ & $\begin{array}{c}-0.008^{* * *} \\
(0.002)\end{array}$ & $\begin{array}{l}0.009 \\
(0.01)\end{array}$ & $\begin{array}{c}0.002 \\
(0.012)\end{array}$ & & $\begin{array}{c}0.030 \\
(0.053)\end{array}$ \\
\hline Low $* 2007-08$ & $\begin{array}{c}-0.009^{* * *} \\
(0.002)\end{array}$ & $\begin{array}{l}-0.005 \\
(0.006)\end{array}$ & & $\begin{array}{l}-0.006 \\
(0.004)\end{array}$ & $\begin{array}{c}-0.014^{* * *} \\
(0.003)\end{array}$ & $\begin{array}{l}-0.005 \\
(0.01)\end{array}$ \\
\hline High$^{*} 2008-09$ & $\begin{array}{l}-0.003 \\
(0.006)\end{array}$ & $\begin{array}{l}-0.003 \\
(0.006)\end{array}$ & $\begin{array}{c}0.003 \\
(0.016)\end{array}$ & & $\begin{array}{c}0.001 \\
(0.011)\end{array}$ & $\begin{array}{c}0.017 \\
(0.037)\end{array}$ \\
\hline Low ${ }^{*} 2008-09$ & $\begin{array}{l}-0.001 \\
(0.002)\end{array}$ & $\begin{array}{l}-0.001 \\
(0.002)\end{array}$ & $\begin{array}{c}0.002 \\
(0.004)\end{array}$ & $\begin{array}{c}-0.00004 \\
(0.004)\end{array}$ & $\begin{array}{l}-0.002 \\
(0.004)\end{array}$ & $\begin{array}{l}0.003 \\
(0.007)\end{array}$ \\
\hline High*Female & $\begin{array}{c}-0.007^{*} \\
(0.004)\end{array}$ & & & $\begin{array}{c}-0.008^{* * *} \\
(0.002)\end{array}$ & $\begin{array}{c}-0.011^{*} \\
(0.006)\end{array}$ & $\begin{array}{c}0.051 \\
(0.059)\end{array}$ \\
\hline Low*Female & $\begin{array}{c}0.001 \\
(0.003)\end{array}$ & & & -0.001 & $\begin{array}{l}0.001 \\
(0.005)\end{array}$ & $\begin{array}{l}0.007 \\
(0.009)\end{array}$ \\
\hline Female*2007-08 & $\begin{array}{c}-0.009 * * * \\
(0.002)\end{array}$ & & & $\begin{array}{c}-0.006^{*} \\
(0.003)\end{array}$ & $\begin{array}{c}-0.012^{* * *} \\
(0.003)\end{array}$ & $\begin{array}{c}-0.005 \\
0.01\end{array}$ \\
\hline Female*2008-09 & $\begin{array}{c}-0.006^{* * *} \\
(0.002)\end{array}$ & & & $\begin{array}{c}-0.006^{* *} \\
(0.002)\end{array}$ & $\begin{array}{c}-0.007 * * \\
(0.003)\end{array}$ & $\begin{array}{l}0.001 \\
0.007\end{array}$ \\
\hline Low*Female*2007-08 & $\begin{array}{c}0.036 \\
(0.022)\end{array}$ & & & $\begin{array}{l}0.0005 \\
(0.013)\end{array}$ & $\begin{array}{l}0.086 \\
(0.059)\end{array}$ & $\begin{array}{c}0.030 \\
(0.041)\end{array}$ \\
\hline High*Female*2007-08 & & & & & & \\
\hline Low*Female*2008-09 & $\begin{array}{c}0.003 \\
(0.005)\end{array}$ & & & $\begin{array}{c}0.010 \\
(0.009)\end{array}$ & $\begin{array}{l}0.007 \\
(0.01)\end{array}$ & $\begin{array}{c}-0.015^{* * *} \\
(0.005)\end{array}$ \\
\hline High*Female*2008-09 & $\begin{array}{c}0.007 \\
(0.021)\end{array}$ & & & & $\begin{array}{c}0.030 \\
(0.055)\end{array}$ & \\
\hline Observations & 57,555 & 36,562 & 20,901 & 23,714 & 22,486 & 10,589 \\
\hline Percent Enrolled & 1.76 & 1.69 & 1.88 & 1.28 & 1.91 & 2.55 \\
\hline
\end{tabular}

Notes: Robust standard errors in parentheses. * indicates significance at a 10 percent level. ** indicates significance at 5 percent level. * indicates significance at a 1 percent level.

HIGH*Female*2007-08 was dropped in all specifications due to very low numbers enrolled in madrassas. 
Figure 1: A map of Khyber Pukhtoonkhwa showing number of attacks by district.

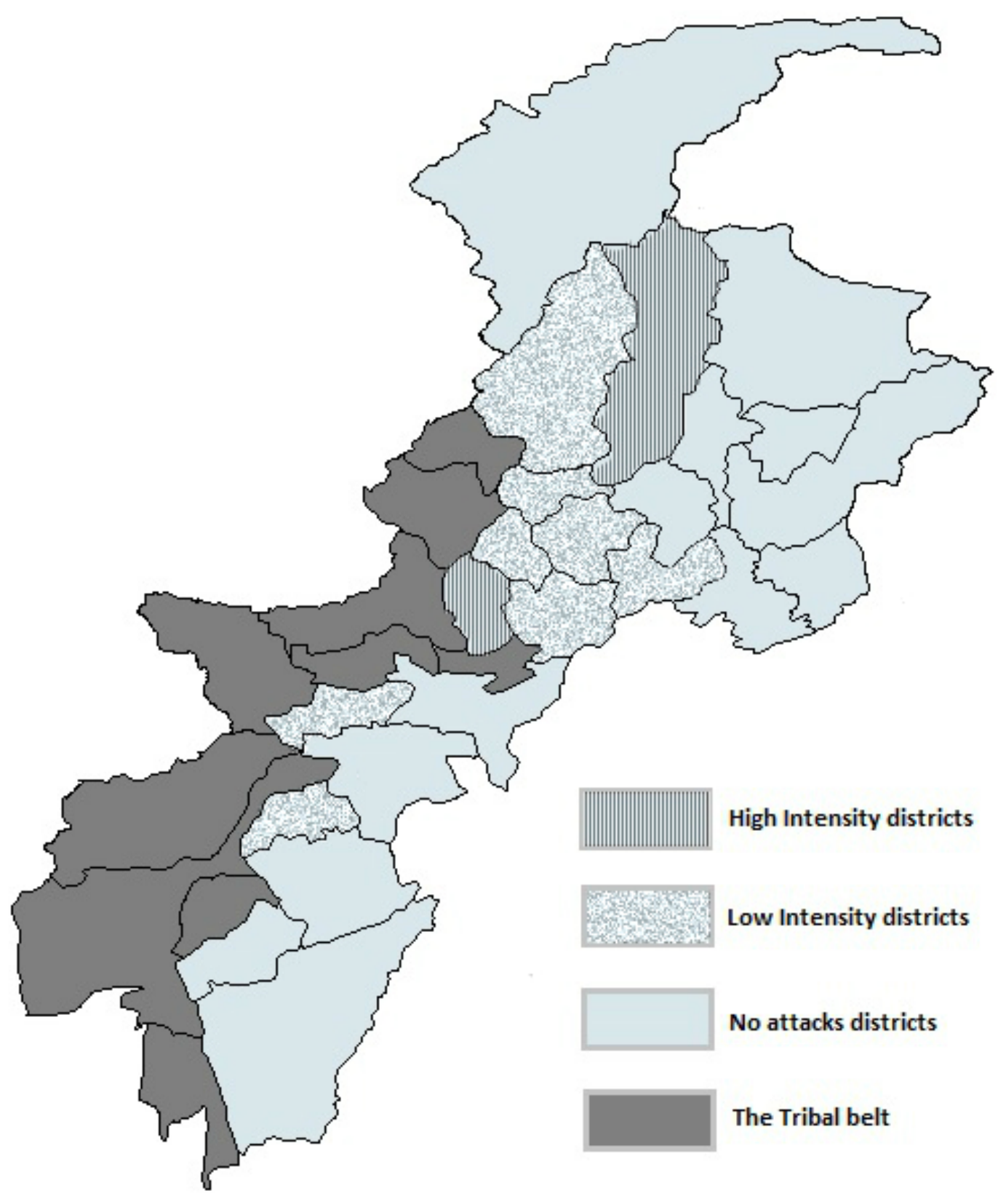




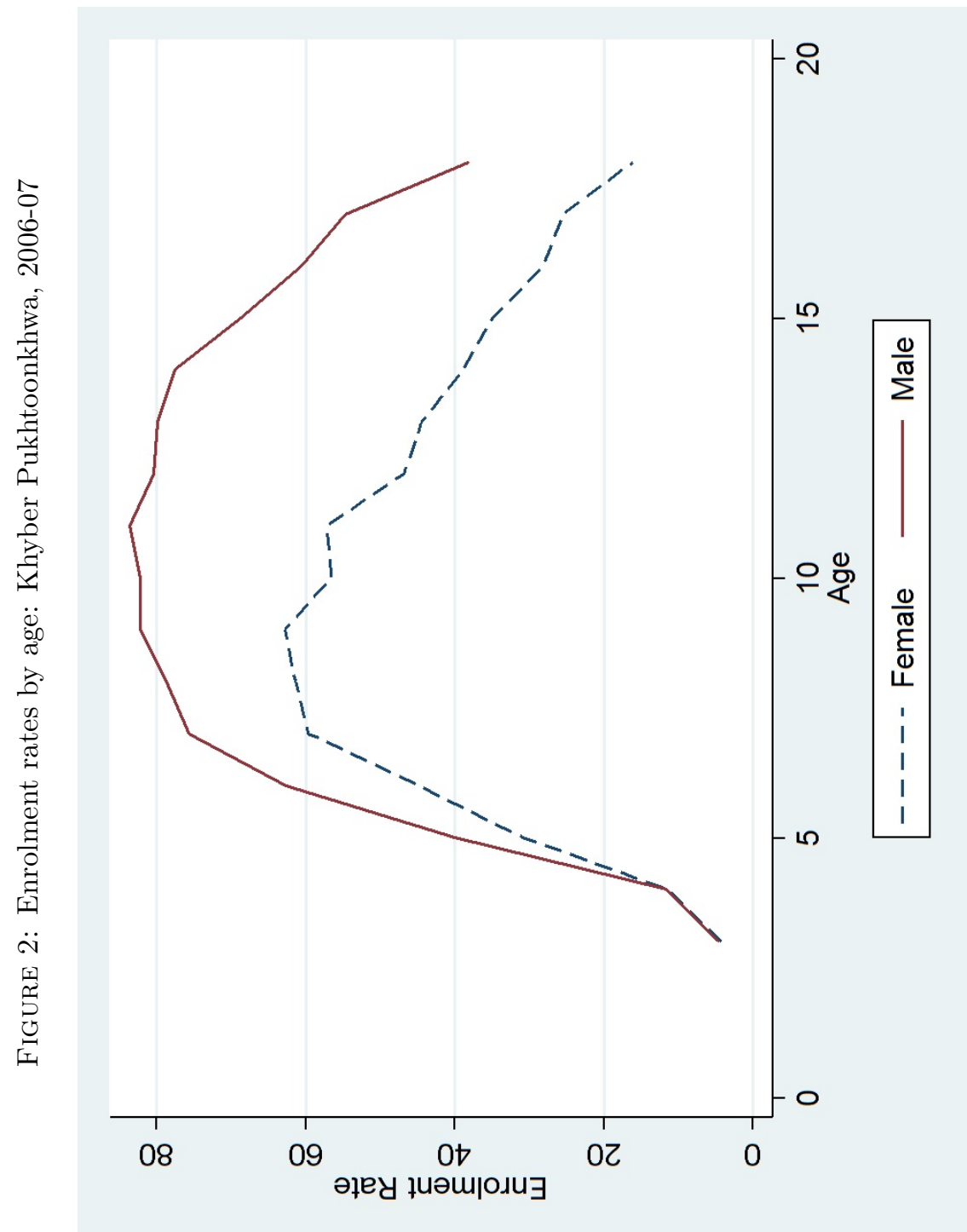




\section{Bibliography}

Abbas, H. (2008). "A Profile of Tehrik-i-Taliban". CTC Sentinal https://www.ctc.usma.edu/posts/a-profile-of-tehrik-i-taliban-pakistan [accessed 19/02/2016].

Akbulut-Yuksel, M. (2014). "Children of War: The Long-Run Effects of Large-Scale Physical Destruction and Warfare on Children". Journal of Human Resources, 2014, 49 (3): 634-662.

Akresh, R. and de Walque, D. (2008). "Armed Conflict and Schooling: Evidence from the 1994 Rwandan Genocide". IZA Discussion Paper No. 3516.

Amin, A. (2008). "Militants Destroyed 125 Girls' Schools in 10 Months." Daily Times (August 21, 2008). http://archives.dailytimes.com.pk/national/21-Aug2008/militants-destroyed-125-girls-schools-in-10-months [accessed 19/02/2016].

Andrabi, T., Das, J., Khwaja, A., and Zajonc, T. (2006). "Religious School Enrolment in Pakistan: A Look at the Data". Comparative Education Review, 50 (3): 446-47\%.

Aslam, M., Kingdon, G., and Söderbom, M. (2008). "Is female Education a Pathway to Gender Equality in the Labor Market? Some Evidence from Pakistan". In Mercy Tembon and Lucia Fort, Editors, Girls' Education in the 21st Century Gender Equality, Empowerment, and Economic Growth (Washington DC, World Bank).

BBC News (2007). "Attack on Giant Pakistan Buddha" (12 September 2007). http://news.bbc.co.uk/1/hi/world/southasia/6991058.stm [accessed 19/02/2016].

Blood, P. (1994). "Pakistan: A Country Study. Washington: GPO for the Library of Congress". http://countrystudies.us/pakistan/42.htm [accessed 28/07/2016]. 
Brumfield, B. (2012). "Who are the Pakistani Taliban?" CNN (October 17, 2012). http://edition.cnn.com/2012/10/17/world/asia/pakistan-taliban-profile/ [accessed 19/02/2016].

Buneri, S. (2012). "Pakistan's Swat Valley - Taliban Gone but Peace Remains Elusive". Pulitzer Centre of Crisis Reporting http://pulitzercenter.org/reporting/pakistan-swatvalley-taliban-fazlullah-afghanistan-border-military, [accessed 19/02/2016].

Chamarbagwala, R. and Morán, H. (2011). "The Human Capital Consequences of Civil War: Evidence from Guatemala". Journal of Development Economics, 94 (1): 41-61.

Currie, J. and Moretti, E. (2003). "Mother's Education and the Intergenerational Transmission of Human Capital: Evidence from College Openings". The Quarterly Journal of Economics, 118 (4): 1495-1532.

Daily Times (2007). "Tailor's Shop Blown Up in Bajaur." (7 September, 2007). http://archives.dailytimes.com.pk/national/07-Sep-2007/tailor-s-shop-blownup-in-bajaur [accessed 19/02/2016].

Dawn News (2009). "Army alarmed as Taliban eye Mardan, Swabi." (24 April, 2009). http://www.dawn.com/news/905219/army-alarmed-as-taliban-eye-mardan-swabi [accessed 19/02/2016].

Focus (2014). "pakistani parents forced to send children to madrassas". http://www.france24.com/en/focus/20140707-2014-07-07-0746-focus [accessed $7 / 6 / 2016]$.

Glewwe, P. and Jacoby, H. (1994). "student achievement and schooling choice in lowincome countries - evidence from ghana".

Global Terrorism Database (2016). GTD. https://www.start.umd.edu/gtd/ [accessed $11 / 03 / 2016]$.

Hayat, K. (2009). "swat militants driving girls out of school." irin news (20 january, 2009).

Jimenez, E. and Tan, J. P. (1987). "Decentralized and Private Education: The Case of Pakistan". World Bank Education and Training Department, http://documents.worldbank.org/curated/en/966181468759316060/Decentralizedand-private-education-the-case-of-Pakistan (accessed 19/07/2016).t. 
Justino, P. (2011). "Violent Conflict and Human Capital Accumulation". MICROCON Research Working Paper, 54.

Khan, R. (2012). "Pakistan Rebuilds its Education Network after Taliban are driven out of Swat." The Guardian (26 June, 2012). http://www.theguardian.com/globaldevelopment/2012/jun/26/pakistan-education-swat-valley-taliban [accessed 19/02/2016].

Michael, G. and Qasim, N. (2011). "Pakistani Girls defy Taliban School Bombings". http://www.reuters.com/article/us-pakistan-taliban-schoolsidUSTRE7AF0GP20111116 [accessed 28/07/2016].

OCHA (2010). "Pakistan - Flood Extent and Flood Losses. United Nations Office for the Coordination of Humanitarian Affairs". www.publications.parliament.uk/pa/cm201012/cmselect/cmintdev/615/61501.gif [accessed 11/03/2016].

Pakistan Bureau of Statistics (2007). "Pakistan Social and Living Standards Measurement Survey (PSLM) 2006-07 (National / Provincial)". http://www.pbs.gov.pk/node/295 [accessed 19/02/2016].

Pakistan Press Foundation (2016). "Religious Extremists Destroyed 25 Music Shops" (4 July, 2007). http://freemuse.org/archives/1006 [accessed 19/02/2016].

PBS Frontline (2010). "Pakistan - the Lost Generation". http://www.pbs.org/frontlineworld/stories/pakistan901/video_index.html. accessed $7 / 6 / 2016$.

Reuters (2007). "Pakistani Barbers Receive Taliban-style Beard Threat" (12 February, 2007). http://www.reuters.com/article/us-pakistan-beards-idUSISL23346120070212 [accessed 19/02/2016].

Shemyakina, O. (2011). "The Effect of Armed Conflict on Accumulation of Schooling: Results from Tajikistan". Journal of Development Economics, 95 (2): 186-200.

South Asia Terrorism Portal (2016). http://www.satp.org/ [accessed 11/03/2016].

Stewart, F. Huang, C. and Wang, M. (2001). "Internal wars in developing countries: An empirical overview of economic and social consequences". In: Frances Stewart, Valpy 
Fitzgerald (Eds.), War and Underdevelopment. Oxford University Press, Oxford, New York, 2001.

Swee, E. (2015). "On War and Schooling Attainment: The Case of Bosnia and Herzegovina”. European Journal of Political Economy, 40: 158-172.

Tavernise, S. (2009). "Pakistan's Islamic Schools Fill Void, but Fuel Militancy." (3 May, 2009). New York Times.

UK Home Office (2012). "Pakistan, Country of Origin Information Report". http://www.refworld.org/pdfid/4fd1fa252.pdf [accessed 19/02/2016].

UNESCO (2010). "Education under Attack". http://unesdoc.unesco.org/images/0018/ 001868/186809e.pdf [accessed 31/05/2016].

United Nations (2016). "Background Paper on Attacks Against Girls Seeking to Access Education". http://www.ungei.org/resources/files/www.ohchr.org_Documents_HRBodies_CEDAW_ Report_attacks_on_girls_Feb2015.pdf [accessed 28/07/2016].

World Bank (2016). "Inflation and Consumer Prices (Annual Percent)". http://data.worldbank.org/indicator/FP.CPI.TOTL.ZG [accessed 29/02/2016].

Zaidi, S. (2010). "Geographic Trajectories of Al-Qaida and Taliban Terrorist Groups in Pakistan". Journal of Strategic Security, 3 (1): 1-18. 